INFORMASI - ISSN (p) 0126-o650; ISSN (e) 2502-3837

Vol. 49. No. 1 (2019). pp 51-63.doi: http://doi.org/10.21831/informasi.v49i1.23348

\title{
ADOPTION OF INFORMATION AND COMMUNICATION TECHNOLOGY TO ENHANCE VETERINARY PHARMACOLOGY EDUCATION IN NIGERIAN UNIVERSITIES
}

\author{
Adamkolo Mohammed Ibrahim \\ adamkolo@unimaid.edu.ng \\ Department of Mass Communication, \\ University of Maiduguri PMB 1069, \\ Borno State, Nigeria \\ Mohammed Bashir Tijjani \\ bashvet@yahoo.com \\ Department of Veterinary Pharmacology and Topology, \\ Faculty of Veterinary Medicine, \\ University of Maiduguri \\ Borno State, Nigeria.
}

\begin{abstract}
In resource-constraint countries like Nigeria, it is envisaged that the adoption of information and communication technology (ICT) in veterinary pharmacologyeducation at university level can enhance both quality knowledge delivery and improve students' performance as well as ICT use skills. The literature consistently demonstrates that exposure to variety of digital and online educational resources and facilities encourages critical thinking among the students and enhance their independent problem-solving capabilities. It is long overdue cost-effective and efficient technology systems suitable for e-learning and teaching in Nigerian university education system, particularly in veterinary pharmacology academic context are explored. Emphasis should be placed on audio-visual e-learning systems such as large screen computer, digital projector and whiteboard in addition to constant power supply and Wi-Fi internet service. Being a medical course, veterinary pharmacology education will be immense enhanced if digital collaborative research and education systems are provided. To achieve this objective, relevant software and applications tailored to veterinary pharmacology students' specific needs in the e-education process are strongly recommended given the rapid innovations in the ICT sector, which is increasingly making both hardwater and software more affordable and user-friendly.
\end{abstract}


Di negara-negara dengan keterbatasan sumber daya seperti Nigeria, diperkirakan adopsi teknologi informasi dan komunikasi (TIK) dalam pendidikan farmakologi veteriner di tingkat universitas dapat meningkatkan penyampaian pengetahuan yang berkualitas dan dapat meningkatkan kinerja siswa serta keterampilan penggunaan TIK. Literatur secara konsisten menunjukkan bahwa paparan berbagai sumber daya dan fasilitas pendidikan digital dan sarana melalui (online) mendorong pemikiran kritis di antara siswa dan meningkatkan kemampuan pemecahan masalah independen mereka. Hal ini sudah lama diharapkan sebagai sebuah sistem teknologi yang hemat biaya dan efisien serta cocok untuk pembelajaran e-learning dan pengajaran di sistem pendidikan universitas Nigeria, terutama dalam konteks akademik farmakologi veteriner yang dieksplorasi. Penekanannya ditempatkan pada sistem-sistem perpustakaan dengan sistem online audio-visual seperti komputer layar besar, proyektor digital dan papan tulis di samping catu daya yang konstan dan layanan internet Wi-Fi. Melalui kursus medis, pendidikan farmakologi veteriner akan mudah ditingkatkan jika penelitian kolaboratif digital dan sistem pendidikan disediakan. Untuk mencapai tujuan ini, perangkat lunak dan aplikasi yang relevan yang disesuaikan dengan kebutuhan spesifik mahasiswa kedokteran hewan dalam proses e-edukasi sangat disarankan mengingat inovasi berkembang cepat di sektor TIK, yang semakin menjadikan air keras dan perangkat lunak lebih terjangkau dan ramah pengguna.

Keywords: Veterinary Pharmacology, e-Library, e-Learning, ICT, Nigerian Universities

\section{INTRODUCTION}

The adoption of innovations is crucial for modernization and development of general education system in Nigeria. Cognizant of this fact, the Federal Government of Nigeria formulated policies and designed programs aimed at establishing foundations of ICT use in education, and ensuring maximum utilization of human and material resources. Nigeria's educational development strategy shifted from sectoral to integrated approach, with emphasis on multi-dimensional elements such as infrastructural development and institutional reforms in order to enhance teaching and learning activities in schools and higher institutions of learning, especially the latter (Ifenkwe, 2008).

The American scholar Everett Rogers is said to be the person who introduced innovation diffusion theory in the context of development. Modernization is here conceived as a process of diffusion whereby institutions of higher learning move from a traditional system of teaching and learning to a different, more technically developed and more rapidly changing system ICT.
Building primarily on sociological research in agrarian societies, Rogers stressed the adoption and diffusion processes of cultural innovation. In this chapter, this approach is therefore concerned with the process of diffusion and adoption of ICT innovative method of teaching and learning in a more systematic and planned way (Servaes, 2008).

The modernization paradigm, dominant in academic circles from around 1945 to 1965 , supported the transferring of technology and the socio-political culture of the developed societies to the 'traditional' societies. Development was defined as economic growth. The central idea in the modernization perspective is the idea of evolution, which implies that development is conceived as first, directional and cumulative, secondly, predetermined and irreversible, thirdly, progressive, and fourthly, immanent with reference to the nation-state. The developed Western societies or modern societies seem to be the ultimate goals which the less developed societies strive to reach (Servaes \& Malikhao, 2008). 
Information and communication technology (ICT) is increasingly gaining more focus in scholarly discourse in research as a means to facilitate not only learning but also teaching that are time and place blind. Many studies have examined how ICT can be harnessed to tap its potential benefits for educational development (Pynoo, Devolder, Tondeur, Braak, Duyk, \& Duyk, 2011) in veterinary pharmacology (Simões, 2010). Progressively, the benefits of using ICT in learning and teaching are being revealed. Hence, the need for advocacy toward policy formulation and implementation regarding theadoptionof ICTinall learningand teaching activities in Nigerian universities, especially in veterinary education. The imperativeness of the use of ICT in veterinary pharmacology education can be more evocative given that it is a career that involves the health, well-being and ultimately life of members of one of the none-human ecosystems in society upon which the human society greatly depends (Nassuora, 2013; Osazuwa, 2011).

ICT has been defined as any device, system and facility that can be employed to collect, process, store and diffuse information (Njoh, 2012). While using ICT in learning, or e-learning has been defined as "learning through electronic devices such as desktop/ laptop computers, CD/DVD players, etc." (Nassuora 2013, p.1). Nowadays ICTs are ubiquitous, and their significance continues to soar in virtually every aspect of human endeavor, especially in intra- and extra-mural education (Pynoo et al., 2011).

The use of ICT in education (e-education) should involve integrating relevant ICT hardware and software into the general educational activities, especially teaching and learning (digital teaching and learning, or what we call e-T\&L) activities. Relevant technologies that can aid in teaching Veterinary Pharmacology in Nigerian universities include use of fully functional electronic libraries where assorted e-books, digital images of various drug dosage forms, video demonstration on practical procedures, video coverages on rare cases and so on and so forth can be easily accessed. Furthermore, the use of customized software applications for use in smartphones developed by institutions or the use of social media can be harnessed to boost veterinary education (Agaga \& John, 2016 June; Oguzor, 2011; Miller, 2011; Reed, 2010).

This chapter seeks to provide further understanding about the issues and trends of the utilization of ICT in teaching vetrinary pharmacology in Nigerian universities. Extant literature was critically reviewed and key themes are highlighted, with a broader outlook of the Nigerian university education system's adoption of ICT in teaching and learning processes, focusing on veterinary pharmacology. The chapter is divided into three broad sections namely, (i) Issues and Problems: in this section, the general focus of the chapter was discussed under several sub-headings; (ii) Solutions and Recommendations: in this section, solutions and recommendations about how to solve the problems identified and address the issues raised in the preceding section are discussed; and finally, (iii) Conclusion: in this section, the main gist of the chapter was concisely discussed with concluding remarks.

\section{LITERATURE REVIEW}

\section{Nigerian Veterinary Curriculum and Modes of Teaching Pharmacology}

Veterinary education curriculum in Nigeria is designed to be covered in six years under various disciplines (NUC). Pharmacology is one of the courses taught as part of the requirements for the award of Doctor of Veterinary Medicine (at Bachelor's degree level). Owing to tight lectures schedules in timetable, average number of required readings and credit loads to cover per semester is 30 units against for counterparts in other disciplines. Assignments are given not only for training them to have acquired independent learning skill but also to cover their syllabus. Lecturers will therefore, find it easy to disseminate lecturer notes within the shortest time period and students will find it easy to assimilate the information using ICT. Students should be allowed to cognitive 
room to consider other fact (Chafe, 2010; Oguzor, 2011).

Because of the high academic rigors, for student to gain admission into must have evidence of exceptional performance. Yet number of drop outs due to low academic performance is increasing. This may not be unconnected with high number of enrolment without corresponding increase in infrastructural capacity and therefore have to compete with limited space for the training. The conventional teaching methods for delivering veterinary instruction are classroom interaction with lectures. Course materials are usually in form of text dictated by the lecturer or given to makes photocopies for student's use and sometimes in form of PowerPoint presentation. Practical sessions are done in the laboratory and clinical session in veterinary teaching hospitals. This is often association with inconveniences of having to sit for long hours for lectures. Appreciations of ICT as applies to veterinary medicine were taught in the curriculum toward the end of the program (Oguzor, 2011; Osazuwa, 2011).

\section{Learning Style of Veterinary Medical Students}

Understanding learning style of veterinary students towards pharmacology is worthwhile in an attempt to devise or modify the teaching method. Pharmacology is an interesting course to many veterinary medical students especially area of prescription writing, drug interaction and therapeutic problem in practical sessions (Agaga \& John, 2016 June; Simões, 2010). Using Felder and Solomon index of learning style medical student's visual and auditory input style method of knowledge delivery (Neel, 2010). Students perform better with introduction of audio-visual aids as part of their instructional materials (Ghosh, Mandal, Biswas, Dalui, Haldar, \& Biswas, 2016). This type of stimulate experiential learning where students use senses in engaging the subject matter by psychomotor domain of learning (Oguzor, 2011; Osazuwa, 2011). This includes ability to learners to perform a task with various levels of competencies articulation, consolidation and naturalization and mastery satisfy overall skills requirements to perform clinical duties. Use of multimedia will benefit percentage of students having this type of learning style (Chafe, 2010).

\section{Level of ICT Integration in Nigerian Universities}

Over the years, the Nigerian education sector has achieved some level of ICT application in public universities. The Federal Government of Nigeria, in the National Policy on Education (Federal Republic of Nigeria, 2004), recognises the prominent role of ICTs in the modern world, and has integrated ICTs into education. Okebukola (1997) and Aduwa-Ogiegbaen and Iyamu (2005), cited in Adomi and Kpangban (2010), explained that new teaching and learning technologies have not been substantially integrated in most (over 90\% of) Nigerian public schools and higher educational institutions. This implies that the chalkboard and textbook continue to dominate classroom activities in most Nigerian public universities. Although efforts have been made to ensure that ICTs are available and used in Nigerian public universities, the level of application is still low. Furthermore, Goshit, (2006) and Kabir and Kadage (2017) observed that most universities, both public and private, do not offer ICT training program.

ICT use allows students to increase individualization of learning. In higher institutions where new technologies are used, students have access to tools that adjust to their attention span and provide valuable and immediate feedback for literacy enhancement (Enuku \& Enuku, 20oo; Kabir \& Kadage, 2017), which is currently not fully implemented in the Nigerian education system (Adomi \& Kpangban, 2010). Although ICT use in higher education learning processes is still at its infancy, more especially with respect to university education, a number of studies have demonstrated the potential of ICT use at higher education in the country (Adedoja, Botha, \& Ogunleye, 
2012; Kabir \& Kadage, 2017; Reed, 2010). One good example of application of ICTs in higher education is a systematic mobile project funded by Partnership for Higher Education in Africa-Educational Technology Initiative (PHEA-ETI), which is currently being executed in the University of Ibadan. The project was developed and designed via the collaborative efforts of various research experts with the aim to provide students access to instructional contents to enable learning at any time and in any place (Kabir \& Kadage, 2017; Adedoja et al., 2012).

The system was designed in such a way that it delivers the required learning materials via mobile phones seamlessly from its learning content management system (LCMS) infrastructure (Kabir \& Kadage, 2017; Reed, 2010). According to the researchers, provision of such learning materials via mobile phones will produce a number of benefits for students, teachers and administrators. The benefits include: (1) Easy distribution and collation of tests, quizzes and surveys, (2) Interaction in real time between the teacher and student, as well as among students, via the forum and chat room, (3) Ease with which notifications of events, deadlines and timetables are sent to each student, and (4) Accessing e-books via mobile phone at about ten to 15 percent of the cost of supplying hard copies.

ICT application and use can improve Nigeria's education system and provide students with better education (Kabir \& Kadage, 2017). A technologically-literate young citizenry will lead to sustainable ICT growth in the country, with the potential to improve telecommunications, media communications, political communications and skilled ICT professionals who will be well-equipped to solve ICT problems (Adomi \& Kpangban, 2010; Goshit, 2006).

The introduction of Computer Based Test by Joint Admission and Matriculation Board in Nigeria, a body charged with the responsibility of admission into Tertiary Schools is an indication of its gradual acceptability in Nigerian educational system (The Nation, 2017). The level of ICT adoption in Nigerian education system, including veterinary medicine education, is estimated at about $90 \%$ at its inception or basic level (Babalobi, 2010), which is abysmally low. Insufficient provision of funds, exorbitant costs of ICT infrastructures procurement, installation and maintenance and epileptic and low voltage electricity supply have been shown to be responsible for the current low level of ICT integration in our educational system (Adedoja et al., 2012; Kabir \& Kadage, 2017). Political will due to lack of awareness of advantages by lawmakers is evidence national budget very low compared with other African countries. This resulted in lack of capital to establish ICT in Nigeria (Ogunmakin, 2018 May; Osazuwa, 2011).

With annual increase in total of enrolment per year as a reflection of increase in general population, students to staff ration is increasing and this may militate against effective knowledge delivery. The philosophy behind massive open online courses (MOOC) is getting wider audience through online course via the web where course materials such as videos, readings, and problem sets are shared in an interactive user forum (Simões, 2010). Apart from general studies, research into the curriculum showed that formal training on ICT in the mainstream veterinary school was not taught in early years in Nigerian Veterinary institutions/colleges (Agaga \& John, 2016 June); sometimes only at an advanced level, close to graduation.

\section{Constraints of ICT Integration in Nigerian Universities}

Consistently, available data (Livsey, 2016; Njoh, 2012; Ogunmakin, 2018 May) have shown that ICT helps to advance Western and Asian countries, while African countries still experience a lag in its implementation, and this continues to widen the digital and knowledge gaps. In a bid to solve this digital divide syndrome, the Association of Vice-Chancellors of Nigerian Universities (AVCNU) held a workshop on the Strategies for ICT Development and access to more affordableinternetbandwidthforuniversities, 
research and higher educational institutions in Nigeria on $26^{\text {th }}$ February, 2008 (Chafe, 2010), and it identified major impediments to the integration of ICT in Nigerian universities' systems as follows: (1) High cost of internet bandwidth: is responsible for lack of adequate interconnectivity between universities and other institutions, which prevents effective communication and resource-sharing. Furthermore, absence of interconnectivity between the universities leads higher educational institutions to act individually and thus unable to benefit from the economy of scale; (2) Lack of adequate internet bandwidth which leads to poor access to e-learning resources; (3) Human capacity constraints which, lead to service delivery problems; (4) Lack of modern learning and collaboration content and tools, which lead to low-quality teaching and research; (5) Inadequate Technical Capacity; and (6) Unstable power supply, which leads to increased network downtimes.

\section{The Role of Internet and Social Media in Education}

In developed countries, live video conferencing system and webinar capability can be done but this is high level ICT that may be difficult to implement. Quality equipment are often needed for sound, speed and connectivity issues and as such feasibility of adopting such as only source of teaching in developing countries like Nigeria is practically challenging. Students can however, be encouraged to adopt less sophisticated technology such as emails, creating blogs in the internet which are free to the users, such as WordPress. In their blogs, the students can create and write and post their assignment and be reviewed in an online forum provided in the internet. Emails are universally accepted means of communication in a scientific community. Information can be shared with minimum discomfort. Zipp application can send messages to deliver heavy messages with ease share group reviews, blogs. Students should be encouraged to have email to familiarise with global trend of communication and knowledge sharing (Chafe, 2010; Ibrahim, Adamu, \& Gujbawu, 2017).

Social media have become an indispensable part of our lives, and they provide student-friendly learning platforms. Nowadays, many students have social media profiles and are given the opportunity to officially connect with their institutions through social media networks such as Facebook, WhatsApp groups, Twitter, Google+ groups and YouTube. These social network sites can be used to communicate campus news, make announcements and provide students with useful information. On Twitter, for example, hashtags (\#) can be initiated to engage students. Discussion hovering around various academic activities study such as sampling and survey can bedone effectively (Ibrahim et al., 2017). Studies have shown that video is an important instrument in electronic teaching and learning context. For example, videos are widely used in internet-based seminars, otherwise known as webinars. Video can be used to engage students and share useful contents that can help them improve their curricular activities, e.g., helping them in their assignments and preps (Jacobsen \& Forste, 2011).

The population of students using social media for learning purposes is ever increasing (Kabir \& Kadage, 2017). Using social media platforms in academic activities can stimulate collaborative learning and peer review activities among colleagues and friends. It can even stimulate the desire to read and write, and this can be useful for students who find it difficult to do so in real life context. Forcing students to read discourages them from developing the flair to study and therefore, the idea of edutainment, or educational games was conceived (Alrahmi, Othman, Yusof, \& Musa, 2015; Livsey, 2016). This allows using social networks in educating students as they are ready to devote time and learn all that without putting much efforts. That contributes to the overall level of intelligence as well as improves writing and reading skills (Chafe, 2010). 


\section{METHODS}

Employing the critical discourse analysis (CDA) as expounded van Dijk (1993) and Lindlof and Taylor (2002), we examined the text in the literature on the application of ICT in education, focusing on vetrinary pharmacology education in Nigerian universities and identified attributes, consquences and values. Cited in Ibrahim and Gambo (2019), van Dijk (1993) and Lindlof and Taylor (2002)

CDAisprimarilyinterestedandmotivated by pressing social issues which can be understood through discourse analysis. CDA aims at analyzing semiosis, that is, how meaning is created and communicated through written, vocal or sign language. It aims to provide basis for the researcher to understand the dialectical relationships between discourse and other elements of social practices. (P.23)

Because literature on this field of research (application of ICT in pharmacology education in Nigerian universities) is still limited, we sourced materials that are rather a bit comprehensive in outlook, such as those that provided further knowledge about education generally (both secondary and tertiary) from relevant online databases and reviewed. Additionally, we selected relevant literture on veterinary pharmacology and then derived conceptual discourse that can be tailored to application of ICT to education delivery (teaching and learning) processes.

Given that e-books and e-journals are much easier to accessed and use, we employed the help of Google search engine and ResearchGate and Google Scholar websites to access electronic resources that are available in public domain free of charge. Most of our e-resources focused on Nigerian issues; and most of them (85\%) were published from 2005 to date. Of the total of 39 cited references, $67 \%$ of them were journal articles.

\section{RESULTS AND DISCUSSION}

\section{The Use of Multimedia as Teaching Aid}

Cognitive abilities of comprehension, remembering, reasoning, problems solving and making decisions depend on a rich combination of words and images (Miller, 2011; Reed, 2010). This is opposed to abstract thinkingwhereability tothinkaboutanobject, principleand ideas not physically present that is usually practiced by mathematicians and related disciplines (Mayer, 2009). Designing course materials in a multimedia fashion can create a scenario of symbolic thinking. This includes the use of pictures, audio recording and video recordings. Research in visual communication highlighted that pictures have several advantages over words, hence, pictures can be used to improve students' learning. Pictures facilitate learning by providing clarifying examples, extra-lingual information, and contexts for interpretation. The use of pictures has also been shown to aid recall memory than the use of words (Reed, 2010).

A previous study has shown that full video demonstration of the experimental procedure enabled the students to acquire first category of psychomotor skills namely imitation. Students able to memorise the steps required in the experimentation and demonstrated that they could imitate the procedure shown to them in the video presentation (Velumani, 2013). Therefore, drug presentation and dosage forms can easily be demonstrated in their teaching and having a mental picture of the drugs would enhance better prescription skills (Babalobi, 2010). Success recorded in treatment of cases handled in the clinic can boost their confidence when the need for their use arises in practice. For example, irrational drug use consequences include mortality, severe toxicityand mayberareconditions that cannot be induced experimentally due to ethical concerns can be recorded to be a teaching aid when encountered accidentally. Such cases when seen in the future, chances are high that students can easily recognize and diagonize them promptly (Agaga \& John, 2016 June). 
Archiving tools can be used for playback in order to teach or reinforce a lesson, especially for students that missed a class, or want to review the lecture session again. Developing course materials in the form of multimedia can be shared via organized local network, or archived in digital libraries or shared over the internet and even social media platform (Ogunmakin, 2018; Osazuwa, 2011).

\section{The Use of Internet and E-Library}

ICTs such as the internet and computers ae increasingly becoming accessible resources for educators to use in their teaching activities, although most teachers and instructors are still struggling to integrate these new technologies in teaching and knowledge provision activities (Oguzor, 2011). The intranet is the website providing networked community where electronic resources can be shared only for the consumption of the authorized persons via the use of computers. These provide opportunities for filteredto-only-required information to meet the learning needs with minimal distractions such as adverts or links. Digital libraries and its associated services can be created using this networking method where information is stored in a digital format and assessable over a network (Ogunmakin, 2018 May).

In addition to print media found in our libraries, electronic libraries provide ease of usability, readability, affordability and accessibility. Material can consist of mixed media i.e. images, video, audio animation which could not be replaced in print. Internet networked libraries (e-libraries) can serve as an effective alternative to conventional libraries, which, in manyinstitutions of higher education are gradually being turned into 'merearchives of antiquated publications' due to many reasons, especially developments in new technologies. One of the key advantages of internet networked libraries is that they can provide multiple points of access to many users simultaneously (Kabir \& Kadage, 2017; Osang, Ngole, \& Tsuma, 2013). An electronic resource allows quicker means of searching, extracting and making reference from the different electronic sources. This will help the student to have relevant information within the shortest of time. It is independent of internet and its attendant subscription charges and distractions that affect reading quality time from ephemeral information such as advertisement and announcement are avoided. Adoption of local area networking also protect from risk of computer virus attack (Chafe, 2010; Oguzor, 2011; Reed, 2010).

\section{ICTs for Development}

ICTs such as computer (Ibrahim et al., 2017) and telecommunication technology, especially the internet, are employed to bridge the information and knowledge divide between the technologically-affluent and the technologically-poor. Having access to the digital highways not only helps improve access to education opportunities but also increases transparency and efficiency in government services, enhance direct participation from the 'used-to-be-silent students' in the democratic process, increase teaching and learning opportunities, enhance student community empowerment by giving a voice to voiceless groups (e.g., students with disability challenges), access to medical information for isolated cases and increase new horizons of learning (Livsey, 2016; Mayo \& Servaes, 1994; Njoh, 2012).

In developing countries' universities, the local appropriation of ICTs is a telecenter or multi-media communication center consisting of a few desktop computers, internet, photocopying and printing services. Access to the internet and World Wide Web (www) can be optional. The use of the mobile and satellite telephony can help students getting access to information needed to improve their education. ICTs can be powerful tools for sharing information, but it is argued that they often cannot solve the learning problems caused by the underlying social, economic and political issues, nor can they change the existing power structures as the information available is not necessarily knowledge. In order to become knowledge, the information has to make sense to the 
student who receive this information (Mayo \& Servaes, 1994; Ogunmakin, 2018 May).

\section{An Outlook of Nigerian Universities Development Indices Ranking}

Currently, in Nigeria, there are 138 universities registered by the National Universities Commission (NUC). Of that total number 40 are owned by the Federal Government (FG), 39 by various State Governments and 59 are privately-owned (Livsey, 2016; US Diplomatic Mission to Nigeria [USDMN], 2017). Because of relative advancements in ICT, particularly the internet, Nigeria is believed to possess the capability for ICT innovation in tertiary education. In 2009, Nigeria was ranked $47^{\text {th }}$ out of 133 countries. Nigeria is also acknowledged to have the capacity to spend on research and development ( $R \& D)$. It was ranked $40^{\text {th }}$ in 2009 (World Economic Forum, 2009). However, unfortunately, Nigerian Government's expenditure in public education (in terms of a \% of GNI) in 2009 was ranked $128^{\text {th }}$ out of nearly 200 countries (Chafe, 2010).

Nigeria was ranked $91^{\text {st }}$ in internet access in schools and $115^{\text {th }}$ in overall quality of scientific research institutions (ITU - WTI, 2008-2009). Only five public universities were listed among the first 100 in Africa in the 2010 Webometrics ranking of top 8,00o universities in the world namely, University of Ilorin (UniLorin) (ranked $55^{\text {th }}$ in Africa, $5,846^{\text {th }}$ in the world); Obafemi Awolowo University (OAU) (ranked 61 $1^{\text {st }}$ in Africa, $6,265^{\text {th }}$ in the world); University of Ibadan (UI) $\left(63^{\text {rd }}\right.$ in Africa, $6,396^{\text {th }}$ in the world); University of Jos (UJ) (ranked $74^{\text {th }}$ in Africa, $7, \mathrm{OoO}^{\text {th }}$ in the world); and University of Lagos (UniLag) (ranked $79^{\text {th }}$ in Africa, $7,246^{\text {th }}$ in the world) (Chafe, 2010; Akinnaso, 2016 December 13).

Furthermore, out of 195 countries, Nigeria was ranked a distant $181^{\text {st }}$ in public spending on education in 2017, which is quite appalling despite global advancement in ICT and educational technology. Like in previous Webometrics rankings, in the 2018
World Universities ranking none of Nigerian universities was listed among the top 100 in the world. However, a little improvement was observed in the African ranking compared to the 2009 with 10 universities making it to the first 100 list, a $50 \%$ improvement. The lucky universities are: (i) UI ranked $12^{\text {th }}$ in Africa, (ii) University of Nigeria Nsukka (UNN) ranked $37^{\text {th }}$, (iii) OAU ranked $39^{\text {th }}$, (iv) Covenant University ranked $42^{\text {nd }}$, (v) Ahmadu Bello University (ABU) ranked 61 ${ }^{\text {st }}$, (vi) UniLag ranked $62^{\text {nd }}$, (vii) UniLorin ranked $67^{\text {th }}$, (viii) University of Port Harcourt (UniPort) ranked $71^{\text {st }}$, (ix) the Federal University of Technology Minna ranked $78^{\text {th }}$ and $(x)$ the Federal University of Technology Akure ranked $79^{\text {th }}$ (Webometrics, 2018). Although a couple of second-generation universities (those established between 1970 and 1985) had made to the first 100 ranking in Africa in 2009, the latest ranking shows that only firstgeneration universities (those established between 1948 and 1965) have been able to make it to the top 100 in Africa except for only one private university, Covenant University.

It is observed that universities of many African countries are ranked better than most Nigerian universities in all areas of advancement, including ICT use and veterinary education. This chapter believes that without a reasonable advancement in the adoption of ICT in teaching and learning (especially in veterinary pharmacology) and basic research infrastructure, the fruition of a knowledge-based economy that is necessary for sustainable development will be unfeasible. Institutions of higher education in the nation are envisaged to champion this process of advancement in educational technology development and generating quality knowledge for national development. Advanced countries like USA, the UK, Australia and Belgium, as well as developing countries such as South Africa, Ghana and Kenya have realized this and are investing heavily in the adoption of ICT in higher education, particularly in science and medical-based disciplines veterinary pharmacology. Implementing a high capacity e-learning system for Nigerian universities should now be a foundational priority for 
teaching and research (Livsey, 2016; Chafe, 2010).

The Association of Vice-Chancellors of Nigerian Universities (AVCNU) held a workshop on the Strategies for ICT Development and access to more affordable internet bandwidth for universities, research and higher educational institutions in Nigeria on $26^{\text {th }}$ February, 2008, and it was emphasized that that ICT is essential for the development of university education as follows: (1) Supporting the development and sharing of online information and e-resources; (2) Supporting collaborative research among Nigerian universities, research and higher educational institutions (in addition to collaborative research with others); (3) Running joint online courses and sharing expertise; (4) Sharing of experiences and best practices; and (5) Providing opportunities for student and staff exchange.

The workshop further resolved to establish a National Research and Education Network (NREN). The workshop identified the following as some of the perceived benefits of the integration of ICT in Nigerian universities' systems: (i) enterprise wide antispam and anti-virus solution, (ii) e-courseware, (iii) e-library, (iv) video conferencing, (v) voice over internet protocol (VoIP), (vi) subscription to e-journals, and (vi) staff/student management and administration.

\section{CONCLUSION}

This chapter believes that using ICT in the teaching of those course can tremendously improve students' performance and motivate teachers to evolve and adopt innovative teaching methods. Pharmacology students taught using ICT facilities are expected to possess better employability characteristics, determination to be successful self-employed persons and innovative mind to be able to more successfully transfer the education acquired in class to the career field (labor market) and into real life practice for national development. This is simplygiven that further explanations to challenges that prompted up during learning process, their solutions and how to apply the solutions to overcome the challenges can be more easily accessed using general ICT such as e-library facilities and Google Scholar, or specific databases online such as PubMed. Psychomotor skills-based teaching strategy utilizing audio-visual aids results in betteracquisition of hands-on skills. Slow learners can also take the advantage of replaying the lecture recordings for desired number of time against the single classroom contact. Therefore, there the need to adopt the global trends of educational reforms even at a rudimentary level and upgrades can be achieved at a phase that agrees with our economic and developmental realities.

Some universities such as University of Maiduguri also make effort to introduce it as a means of assessing students in their regular semester examinations. Even without enabling environment for full implementation of ICT: electricity, phones and computers, undergraduate program supported by information and communications technology can make veterinary training. Access to audio-visuals video archiving: engagement of conative mood of learning, text explanation obscure, a lot of explanation for 5 minutes clips. Intranet Instant access to learning resources and e-library lessens time for than use of google and other search engines maximize optimum rest in learning. Official email group for Faculty and that of each levels of study can be created in addition to Notice Board to stimulate students to imbibe the culture of depending on. There is need for research into actual student's opinion of learning method will inform and transform teaching methods.

In view of the preceding discussion, this chapter believes that if ICT integration in higher educational systems is prioritized (including veterinary pharmacology education), a tremendous improvement will be achieved; notably regarding the $50 \%$ improvement recorded in the Africa ranking of Nigerian universities from 2009 to 2018, which implies that over the decade, the modest advancement in the integration of e-learning systems in some 
Nigerian universities has contributed toward the present improvement (Livsey, 2016). Hence, it this chapter recommends that the following, as enunciated in Chafe (2010) and Ogunmakin (2018 May), should be provided on a sustainable basis: (1) a high capacity connectivity that allows the institutions to communicate and collaborate effectively with each other (e.g., voice over internet protocol [VoIP], video conferencing, remote experimentation, etc) and with hosted central resources, without incurring additional network costs; (2) adequate internet bandwidth to access internet-based resources for research and learning; (3) centralization of applications and resources (e.g., e-books, e-journals, open courseware, etc) that are best hosted at a 'hub' location; (4) consolidated co-management of network; (5) increasing capacity and affordability of alternative power including inverter, solar and wind technologies; (6) capacity building for various stakeholders (e.g., lecturers, technicians); and (7) economies of scale as pooled resources work out cheaper when costs are factored on a per institution basis. For example, as of 2010, the cost of internet bandwidth per university was \$4,250 (N1.55 million) per mbps/month via weather and electromagnetic energy-impacted VSAT; in 2018 , it costs $\$ 2,300$ (N840,0oo) per mbps/ month. Predicted cost is expected to be $\$ 1,500$ ( $\mathrm{N}_{548,000}$ ) per mbps/month via faster and more reliable marine cable.

\section{REFERENCES}

Adedoja, G., Botha, A., \& Ogunleye, O. S. (2012). The future of mobile learning in the Nigerian education system. In P. Cunningham \& M. Cunningham (Eds.), IST-Africa 2012 Conference Proceedings. IIMC International Information Management Corporation, 2012.

Adomi, E. E. \& Kpangban, E. (2010). Application of ICTs in Nigerian secondary schools. Library Philosophy and Practice (e-journal), paper 345. Accessed from http://digitalcommons. unl.edu/libphilprac/345

Aduwa-Ogiegbean, S. E. \& Iyamu, E. O. S. (2005). Using information and communication technology in secondary schools in Nigeria. Educational Technology E Society, 8(1), 104-112.

Agaga, L. A. \& John, T. A. (2016 June). Conception of pharmacological knowledge and needs amongst Nigerian medical students at Lagos State University College of Medicine: Implication for future biomedical science in Africa. Nigerian Journal of Physiological Science, 31, 083-091.

Akinnaso, N. (2016 December 13). 'What's your university's rank in the world?' Punch Nigeria. Accessed from https:// www.punchng.com/

Al-rahmi, W. M., Othman, M. S., Yusof, L. M., \& Musa, M. A. (2015). Using social media as a tool for improving academic performance through collaborative learning in Malaysian higher education. Review of European Studies, 7(3), 265275. doi: 10.5539/res.v7n3p265

Babalobi, O. O. (2010). Internet web communication technology and information communication technology development and use for veterinary medicine education in Nigeria (2000-2009). Nigerian Veterinary Journal, 31(3), 185-194. doi: 
10.4314/nvj.v31i3.68976

Carlile, S., Barnet, S., Sefton, A., \& Uther, J. (1998). Medical problem based learning supported by intranet technology: A natural student-centered approach. International Journal of Medical Informatics, 5o(1-3), 225-233

Chafe, A. I. (2010). Nigerian universities ICT solution project. PowerPoint slides presented at Nigerian Universities ICT Solution Project, NUC STEP-B Project Team. National Universities Commission (NUC), Abuja. Retrieved 17 November, 2018 from www.forum. org.ng

Enuku, U. A., \& Enuku, O. (200o). Breaking down the walls: Computer application in correctional/prison education. Benin Journal of Educational Studies, 12/13(1/2), 64-71.

Federal Republic of Nigeria. (2004). National policy on education, $4^{\text {th }}$ ed. Lagos: Nigerian Educational Research and Development Council.

Field, M. J. J. \& Sefton, A. J. (1998). Computerbased management of content in planning a problem-based medical curriculum. Medical Education, 32(2), 163-171.

Ghosh, A., Mandal, K., Biswas, S., Dalui, S. K., Haldar, M., \& Biswas, S. (2016). Evaluation of pharmacology teachinglearning methods in government medical colleges. International Journal of Basic and Clinical Pharmacology, 5(1), 126-130.

Goshit, T. (2006). Nigeria's need for ICT: ES.259 Technology and policy in Africa. In ES.259 information and communication technology in Africa, MIT Open courseware. Accessed from http://ocw.mit.edu/NR/rdonlyres/ Special-Programs/SP-259Spring2006/891209EE-E63B-4617-BA9D7635A63C $754 \mathrm{~B} / \mathrm{o} /$ goshit.pdf

Ibrahim, A. M., Adamu, M. A., \& Gujbawu, M. (2017). Analysis of the expectation of effort expended when ICT is used in academic activity: Influence of effort expectancy and moderating role of experience. Mass Communication Currents, 1(1), 19-38.

Ibrahim, A. M. \& Gambo, D. (2019). Stakeholder perception of the impacts of communication for development techniques in NGO-supported organizational capacity building: a case of Yobe State Primary Health Care Management Board. Developing Country Studies, 9(3), 17-30. doi: 10.7176/DCS

Ifenkwe, G. E. (2008). Assessment of newspaper advocacy for rural development and environmental education in Nigeria. Journal of Agricultural Extension, 12(2), 41-51.

Jacobsen, W., \& Forste, R. (2011). The wired generation: Academic and social outcomes of electronic media use among university students. CyberPsychology, Behavior, and Social Networking, 14(5), 275-280.

Kabir, F. S. \& Kadage, A. T. (2017). ICTs and educational development: The utilization of mobile phones in distance education in Nigeria. Turkish Online Journal of Distance Education-TOJDE, 18(1), 63-76.

Lindlof, T. R., \& Taylor, B. C. (2002). Qualitative communication research methods. Thousand Oaks, CA: Sage.

Livsey, T. (2016). Imagining an imperial modernity: Universities and the West African roots of colonial development. Journal of Imperial and Commonwealth History, 44(6), 952-975.

Matthew, D., Joro, I. D., \& Manasseh, M. (2015). The role of information communication technology in Nigeria educational system. International Journal of Research in Humanities and Social Studies, 2(2), 64-68.

Mayer, R. E. (2009). Multimedia learning, $2^{\text {nd }}$ ed. Cambridge: Cambridge University 
Adamkolo Mohammed Ibrahim and Mohammed Bashir Tijjani, Adoption of Information and Communication ...

Press.

Mayo, J. \& Servaes, J.(Eds.). (1994).Approaches to development communication: A training and orientation kit (Vol. 1). New York: UNFPA/UNESCO.

Miller, O. (2011). The processing of pictures and written words: A perceptual and conceptual perspective. Psychology, 2(7), 713-720.

Nassuora, A. B. (2013). Students acceptance of mobile learning for higher education in Saudi Arabia. International Journal of Learning Management Systems, 1(1), 1-19.

Neel, J. A. (2010). Learning style profile of 150 veterinary medicine students. Journal of Veterinary Medicine Education, 37(4), 347-352. doi: 10.3138/jvme.37.4.347

Njoh, A. J. (2012). Implications of spatial and physical structures for ICT as a tool of urban management and development. Habitat International, 36(3), 343-351. doi: 10.1016/j.habitatint.2011.06.006

Ogunmakin, R. (2018 May). Internet capacity of higher education and research institutions in Africa: the need for national research education network. American Journal of Educational Research, 6(6), 586-591. doi: 10.12691/ education-6-6-1

Oguzor, N. S. (2011) Computer usage as instructional resources for vocational training in Nigeria. Educational Research and Reviews, 6(5), 395-402.

Okebukola, P. (1997). Old, new and current technology in education. UNESCO Africa, 14(15), 7-18.

Osazuwa, R.J. (2011). The effect ofICT, research and education network in improving the quality of research and higher education. A paper presented at the Conference of Rectors, Vice Chancellors and Presidents (COREVIP 2011), Association of African Universities, Nay 30 to June 3, Stellenbosch, South Africa.

Pynoo, B., Devolder, P., Tondeur, J., van Braak, J., Duyk, W. \& Duyk, P. (2011).
Predicting secondary school teachers' acceptance and use of a digital learning environment: A cross-sectional study. Computers in Human Behaviour, 27, 568-575.

Reed, S. K. (2010). Thinking visually. New York: Psychology Press.

Servaes, J.\& Malikhao, P.(20o8).Development communication approaches in an international perspective. In J. Servaes (Ed.), Communication for development and social change (pp. 158-179). Los Angeles: Sage.

Simões, J. (2010). Information communication technology applied to veterinary education in early XXI century. Veterinaria.com.pt, 3(1), 1-29. Accessed from http://www.veterinaria. com.pt/media/DIR_27001/VCP2-1-e1. pdf

The Nation (2017). 'The JAMB revolution.' The Nation. Accessed from http:// thenationonlineng.net/the-jambrevolution/

US Diplomatic Mission to Nigeria [USDMN]. (2017). Nigeria: Education profile, 17 August. Accessed from https://nigeria. usembassy.gov/nigeria_education_ profile.html

Van Dijk, T. A. (1993). Principles of critical discourse analysis. Discourse and Society, 4(2), 249-283. doi: 10.1177/0957926593004002006

Velumani, K. V. (2013). An investigation in to the impact of e-resources in modern library and information centers. Doctoral dissertation, Department of Library and Information Science, Alagappa University, India. Accessed from https://hdl.handle. net $/ 10603 / 54204$

Webometrics (2018). Ranking web of universities: Africa. Accessed from https://www.webometrics.info/ 